\title{
IMPLEMENTASI SISTEM MANAJEMEN MUTU (SMM) ISO 9001:2008 DI SMK MA'ARIF 1 WATES KULON PROGO
}

\author{
Maryadi, dan Lantip Diat Prasojo \\ Universitas Negeri Yogyakarta \\ Email: maryadispdt@yahoo.com
}

\begin{abstract}
Abstrak
Tujuan penelitian adalah untuk mengetahui implementasi SMM ISO 9001:2008, hambatan dan penyelesaiannya dalam implementasi SMM ISO 9001:2008. Penelitian ini menggunakan desain campuran untuk mendeskripsikan implementasi SMM ISO 9001:2008. Penelitian dilakukan di SMK Ma'arif 1 Wates dengan subjek kepala sekolah, wakil kepala, QMR, guru, orang tua siswa, dan siswa. Objek penelitian adalah SMM ISO 9001:2008. Pengumpulan data menggunakan lembar pengamatan dokumen, kuesioner dan wawancara. Tingkat implementasi SMM ISO dinyatakan dalam bentuk persentase. Hasil penelitian ini menyimpulkan bahwa di SMK Ma'arif 1 Wates, implementasi SMM ISO 9001:2008 memperoleh nilai fokus pada pelanggan 83,95\%, kepemimpinan 65,53\%, partisipasi karyawan $76,67 \%$, pendekatan proses $72 \%$, pendekatan sistem $75 \%$, perbaikan berkelanjutan 75,13\%, pendekatan faktual $64 \%$, hubungan pemasok 74,64\%. Hambatan yang terjadi dalam implementasi SMM ISO 9001:2008 adalah pada pendekatan faktual dalam pengambilan keputusan kurang efektif. Penyelesaian hambatan tersebut adalah dengan melakukan penetapan data, penghimpunan data yang sesuai dan efektif, dan analisis data kefektifan sistem manajemen mutu.
\end{abstract}

Kata kunci: implementasi, Sistem Manajemen Mutu (SMM) ISO 9001:2008

\section{THE IMPLEMENTATION OF QUALITY MANAGEMENT SYSTEM (QMS) ISO 9001: 2008 IN SMK MA'ARIF 1 WATES KULON PROGO}

\begin{abstract}
The purpose of this study is to determine the implementation of QMS ISO 9001: 2008, the constraints and the solutions in the implementation of QMS ISO 9001: 2008. This study used a mixed design to describe the implementation of QMS ISO 9001: 2008. The setting was SMK Ma'arif 1 Wates with the subject principals, deputy head, QMR, teachers, parents, and students. The objects of this study were QMS ISO 9001: 2008. The data was collected through the observation sheet documents, questionnaires and interviews. The ISO QMS implementation level was in a percentage. The results of this study show that in SMK Ma'arif 1 Wates, implementation of QMS ISO 9001: 2008 obtained a value of customer focus $83.95 \%$, leadership $65.53 \%$, employee participation $76.67 \%$, process approach $72 \%$, system approach $75 \%$, continual improvement $75.13 \%$, factual approach $64 \%$, and supplier relationships $74.64 \%$. The constraint that occurs in the implementation of QMS ISO 9001: 2008 is in the management principle of factual approach to decision making, and the solution is the determination of the data, appropriate and effective data collection, and the analysis of the effectiveness of the quality management system.
\end{abstract}

Keywords: implementation, Quality Management System (QMS) ISO 9001: 2008 


\section{PENDAHULUAN}

Bagi setiap sekolah peningkatan mutu pendidikan merupakan agenda utama dalam memenangkan persaingan di dunia pendidikan. Peningkatan mutu pendidikan dimulai dengan komitmen pimpinan sekolah. Salah satu komitmen konkrit yang dilakukan pimpinan sekolah dalam meningkatkan kualitas pendidikan adalah dengan menerapkan sistem manajemen mutu (SMM). Penerapan SMM ISO 9001:2008 diharapkan mampu memudahkan proses manajemen sekolah secara efektif dan efisien harapannya adalah mampu meningkatkan kualitas pendidikan. SMM ISO 9001:2008 adalah salah satu 'tools' untuk menciptakan perubahan menuju ke arah perbaikan yang berkelanjutan dalam sebuah organisasi. Implementasikan SMM ISO 9001:2008 diawali dengan komitmen manajemen. Komitmen manajemen merupakan satu hal penting yang menjadi prasyarat dalam implementasi SMM ISO 9001:2008 pada organisasi apapun, termasuk sekolah. Pada SMM ISO 9001:2008 terdapat delapan prinsip manajemen yaitu: fokus pelanggan, kepemimpinan, dukungan (participation) karyawan, pendekatan proses, pendekatan sistem terhadap manajemen, perbaikan berkesinambungan, pendekatan faktual dalam pengambilan keputusan, dan hubungan pemasok yang saling menguntungkan. Dengan melaksanakan 8 prinsip manajemen pada ISO 9001:2008 diharapkan dapat berdampak pada efektititas kinerja organisasi. Untuk mendapatkan data-data tentang implementasi SMM ISO 9001:2008 perlu dilakukan evaluasi. Tujuan dari evaluasi ini adalah untuk mengetahui keterlaksanaan kebijakan, bukan hanya pada kesimpulan sudah terlaksana dengan baik atau tidaknya, tetapi untuk mengetahui kalau belum baik implementasinya, apa yang telah menyebabkan, di mana letak kelemahannya, dan kalau lemah apa sebabnya (Arikunto, 2010:37). Di Kulon
Progo terdapat sekolah swasta terbesar yang telah menerapkan SMM ISO 9001:2008 yaitu SMK Ma'arif 1 Wates. SMK Ma'arif 1 Wates telah mendapatkan sertifikat SMM ISO 9001:2008 tahun 2011. SMK tersebut mengimplementasikan SMM ISO 9001:2008 dalam rangka rencana strategis SMK untuk pencapaian visi dan misi sekolah. Untuk mengetahui tingkat implementasi pada sekolah tersebut maka perlu dilakukan evaluasi implementasi SMM ISO 9001:2008 yang ada pada sekolah tersebut. Dengan melakukan evaluasi maka akan dapat mengetahui hambatannya dan penyelesaiannya dalam implementasi SMM ISO di sekolah tersebut.

Untuk meningkatkan mutu pendidikan sekolah perlu menerapkan manajemen pendidikan yang baik. Konsep mutu pendidikan menurut para ahli adalah sebagai berikut: "Konsep kualitas dianggap sebagai ukuran relatif kebaikan suatu produk atau jasa yang terdiri atas kualitas desain dan kualitas kesesuaian" (Tjiptono \& Diana, 2003:2). Konsep kualitas atau mutu yang lain dikemukakan oleh Feigenbaum (1992:6) "Mutu adalah sesuatu yang diputuskan oleh pelanggan, bukan oleh insinyur, bukan pula oleh pemasaran atau manajemen umum". Dari kedua konsep kualitas di atas dapat disimpulkan bahwa kualitas atau mutu adalah ukuran relatif kebaikan suatu produk atau jasa yang terdiri atas kualitas desain dan kualitas kesesuaian sesuatu yang diputuskan oleh pelanggan, atau dengan kata lain pelanggan adalah orang yang menilai bahwa barang atau jasa yang dihasilkan oleh produsen atau organisasi itu bermutu atau tidak bermutu.

Mutu didasarkan pada pengalaman aktual pelanggan terhadap produk atau jasa, diukur berdasarkan persyaratan pelanggan yang dinyatakan atau tidak dinyatakan, disadari atau hanya dirasakan, dikerjakan secara teknis atau bersifat subyektif dan selalu mewakili sasaran 
yang bergerak dalam pasar yang penuh persaingan. Lebih lanjut Feigenbaum, (1992:7) mendefinisikan "Mutu produk dan jasa yaitu keseluruhan gabungan karakteristik produk dan jasa dari pemasaran, rekayasa, pembikinan dan pemeliharaan yang membuat produk dan jasa yang digunakan memenuhi harapanharapan pelanggan". Kemudian Gaspersz (2002:4) mendefinisikan "Kualitas adalah segala sesuatu yang mampu memenuhi keinginan atau kebutuhan pelanggan (meeting the needs of customers)".

Produk yang bermutu merupakan keinginan pelanggan. Organisasi berusaha memenuhi keinginan pelanggan dengan meningkatkan mutu produk. Walau demikian, mutu adalah suatu konsep yang tidak mudah dijelaskan dan sulit diukur. Satu hal yang pasti, mutu merupakan suatu hal yang membedakan antara yang baik dengan yang sebaliknya. Hal tersebut seperti yang dikemukakan oleh Sallis (1993:11) sebagai berikut: "Quality is what makes the difference between things being excellent or run-of-the-mill. Increasingly, in education quality makes the difference between success and failure". Dari beberapa pendapat di atas dapat disimpulkan sebagai berikut: kualitas adalah ukuran relatif kebaikan suatu produk atau jasa yang terdiri atas kualitas desain dan kualitas kesesuaian yang diputuskan dan didasarkan oleh pelanggan didasarkan pada pengalaman aktual pelanggan terhadap produk atau jasa yang digunakan untuk memenuhi harapan-harapan pelanggan. Intinya adalah kualitas produk dan jasa merupakan implementasi dari pemenuhan harapan yang diinginkan oleh pelanggan.

Manajemen pendidikan adalah seni dan ilmu mengelola sumber daya pendidikan untuk mewujudkan proses dan hasil belajar peserta didik secara aktif, kreatif, inovatif, dan menyenangkan dalam mengembangkan potensi dirinya. Manajemen adalah seni dan ilmu mengelola sumber daya pendidikan mencapai tujuan pendidikan secara efektif dan efisien. Sumber daya pendidikan adalah sesuatu yang dipergunakan dalam penyelenggaraan pendidikan yang meliputi $7 \mathrm{M}+11$. Manajemen pendidikan adalah proses perencanaan, pengorganisasian, pengarahan, dan pengendalian sumber daya pendidikan untuk mencapai tujuan pendidikan secara efektif, efisien, mandiri, dan akuntabel. Administrasi pendidikan sebagai tugas dapat didefinisikan sebagai administrasi sekolah (Usman, 2013:13). Pendapat yang lain "Management is the process of planning, organizing, leading, and controlling the efforts of organization members and of using all other organizational resources to achieve stated organizational goals" (Stoner, 1995:10). Secara garis besar manajemen pendidikan menurut Stoner (1995:10) adalah sebagai berikut: "Educational management is field of study and practice concerned with the operation of educational organizations". Dari ketiga pendapat tersebut jika ditarik benang merah dapat dijelaskan bahwa manajemen pendidikan adalah seni untuk melaksanakan suatu pekerjaan yang meliputi proses perencanaan, pengorganisasian, pengarahan, pengawasan/pengontrolan usaha-usaha para anggota organisasi pendidikan dan penggunaan sumber daya organisasi untuk mencapai sasaran atau tujuan pendidikan secara terencana dengan benar sesuai dengan jadwal yang telah ditetapkan sebelumnya agar efektif dan efisien.

Dalam konteks pendidikan, konsep kualitas mengharuskan penyelenggara pendidikan memahami dan menyadari bahwa produk lembaga bukanlah barang, melainkan jasa layanan pendidikan. "Quality in education is an evaluation of the process of educating which enhances the need to achieve and develop the talents of the customers of the process, and at the same time meets the accountability standards set by the clients who pay the process or the outputs from the process of educating" (Hoy, 2008:10). Menurut pendapat yang lain kualitas dituliskan sebagai "The quality of a country's education system is a major 
determinant of the quality of its labor pool. The higher the quality of the labor pool, the higher the quality of entry-level employees. The higher the quality of entry-level employees, the faster they can become productive employees and contribute to their employers' competitiveness. Consequently, a highquality education system is an important component of the competitiveness equation"(Goetsch \& Davis, 2000:8). Dari kedua pendapat dijelaskan bahwa kualitas bidang pendidikan adalah evaluasi dari proses pendidikan dalam rangka peningkatan dan perbaikan secara terus menerus untuk memenuhi kebutuhan, keinginan dan harapan para pelanggan pada saat ini dan untuk masa yang akan datang sesuai standar akuntabilitas yang telah ditetapkan serta kualitas sistim pendidikan mempengaruhi tingkat penyiapan tenaga kerja dan gaya manajerial kepala sekolah yang mampu bersaing pada tingkat global. Seperti halnya penelitian yang dilakukan oleh Hoque (2011:3627) dalam peningkatan mutu sekolah menemukan bahwa "..that the comprehensive managerial style for principals can contribute to the school improvement". Gaya manajerial yang komprehensif untuk kepala sekolah dapat memberikan kontribusi terhadap peningkatan kualitas sekolah.

ISO 9001 merupakan standar international yang mengatur tentang sistem manajemen Mutu (Quality Management System), oleh karena itu seringkali disebut sebagai "ISO 9001, QMS" adapun angka 2008 menunjukkan tahun revisi, maka ISO 9001:2008 adalah sistem manajemen mutu ISO 9001 hasil revisi tahun 2000. Dukungan pemerintah dalam peningkatan mutu pendidikan diwujudkan dengan menerapkan anggaran pendidikan sebesar 20\% dari APBN. Kemudian melalui kementrian pendidikan dan kebudayaan menyusun garis garis besar program pembinaan SMK (GBPP SMK). Dalam GBPP SMK, disebutkan bahwa "substansi inti kualitas, diarahkan pada penyiapan dokumen mutu untuk sertifikasi ISO 9001:2008, pemenuhan 8 (delapan) Standar Nasional Pendidikan, serta peningkatan kompetensi lulusan agar dapat bersaing di dunia kerja" (Direktorat Pembinaan SMK, 2012:3). Kemudian pada tahun 2013 disusun GBPP SMK 2013 oleh Kemendikbud. GBPP 2013 berisi tentang petunjuk teknis pelaksanaannya. Dalam GBPP SMK 2013 tertuang misi dari direktorat pembinaan SMK. yang salah satunya adalah "Memperkuat tata kelola SMK melalui penerapan sistem manajemen mutu berbasis ISO 9001:2008" (Direktorat Pembinaan SMK, 2013:17).

Seiring perkembangan zaman dan kemajuan teknologi, terutama semakin luasnya dunia usaha, maka kebutuhan akan pengelolaan sistem manajemen mutu semakin dirasa perlu dan mendesak untuk diterapkan pada berbagai scope industri yang semakin hari semakin beragam.

Dalam (ISO, 2008:1) disebutkan bahwa: This International Standard specifies requirements for a quality management system where an organization. Dalam ISO ini dimuat (1) Needs to demonstrate its ability to consistenly provide product that meets costumer and applicable statutory and regulatory requirements, dan (2) Aims to enhance customer satisfaction through the effective application of the system, including prosesses for continual improvement of the system and the assurance of conformity to customer and applicable statutory and regulatory requirements. Dari Quality Management Systems - Requirement di atas dapat dijelaskan bahwa apabila sebuah organisasi ingin menerapkan standar internasional ini perlu menentukan persyaratan sebagai berikut yaitu (1) Perlu memperagakan kemampuannya untuk secara konsisten menyediakan produk yang memenuhi persyaratan pelanggan dan persyaratan perundang-undangan dan peraturan yang berlaku, dan (2) bertujuan meningkatkan kepuasan pelanggan memalalui penerapan sistemnya secara efektif, termasuk proses perbaikan 
berkelanjutan, sistemnya dan kepastian kesesuaiannya pada persyaratan pelanggan dan persyaratan perundang undangan dan peraturan yang berlaku. Lebih lanjut (ISO, 2005:v) disebutkan bahwa "ISO 9001 specifies requirements for a quality management system where an organization needs to demonstrate its ability to provide products that fulfil customer and applicable regulatory requirements and aims to enhance customer satisfaction". Dapat dijelaskan bahwa pada dasarnya ISO 9001 menetapkan persyaratan untuk sistem manajemen mutu di mana organisasi perlu menunjukkan kemampuannya untuk menyediakan produk yang memenuhi persyaratan pelanggan, peraturan yang berlaku dan bertujuan untuk meningkatkan kepuasan pelanggan.

Pelanggan pada sekolah adalah siswa dan orangtua siswa yang merupakan pengguna produk yang dihasilkan oleh sekolah (Gaspersz, 2002:76). Organisasi tergantung pada pelanggan mereka. Karena itu, manajemen organisasi harus memahami kebutuhan pelanggan sekarang dan akan datang, harus memenuhi kebutuhan pelanggan dan giat berusaha melebihi ekspektasi pelanggan. Dalam (ISO, 2005:v) disebutkan bahwa "Organizations depend on their customers and therefore should understand current and future customer needs. Should meet customer requirements and strive to exceed customer expectations." Dari kedua pengertian di atas dapat dijelaskan bahwa organisasi bergantung pada pelanggannya dan karenanya hendaknya memahami kebutuhan pelanggan saat ini dan masa depan, harus memenuhi persyaratan pelanggan dan berusaha melebihi harapan pelanggan. Oleh karena itu sekolah yang telah menerapkan SMM ISO 9001:2008 akan melaksanakan prinsip manajemen yang berfokus pada pelanggan. Salah satu wujud dari fokus pada pelanggan adalah meningkatkan mutu pembelajaran. Pembelajaran dikatakan bermutu apabila guru telah mengimplementasikan dokumen mutu guru dalam setiap kegiatan pembelajaran. Dokumen mutu guru dalam pembelajaran meliputi penyusunan program, bukti melaksanakan kegiatan belajar mengajar, melaksanakan evaluasi, melaksanakan analisis hasil evaluasi, melaksanakan perbaikan dan pengayaan. Penyusunan program pembelajaran meliputi penyusunan standar kompetensi, Standar kompetensi lulusan, pemetaan materi pelajaran, kriteria ketuntasan minimal, program tahunan, program semester, program penilaian semester, pengembangan silabus, pengembangan silabus. Bukti melaksanakan pembelajaran meliputi agenda mengajar, presensi siswa, dan agenda guru. Dalam melaksanakan evaluasi guru dituntut untuk membuat kisi-kisi ulangan, melakukan penyusunan soal ulangan, adanya catatan tugas dan buku nilai. Kemudian guru dituntut untuk melakukan analisis hasil evaluasi belajar, ketuntasan belajar, menghitung daya serap dan adanya catatan pengembalian pekerjaan siswa. Untuk menindak lajuti hasil pembelajaran guru dituntut untuk melaksanakan perbaikan dan pengayaan yang meliputi penyusunan program perbaikan dan pengayaan, menunjukkan bukti hasil dari pelaksanaan perbaikan dan pengayaan, buku bimbingan hasil belajar siswa merupakan rekaman dari perbaikan dan pengayaan. Selama melakukan pembelajaran sering terjadi kasus yang dilakukan oleh siswa. Kasus kasus tersebut ditulis dalam catatan kasus. Pelanggan dalam pandangan tradisional adalah orang yang membeli dan menggunakan produk. Kalau dalam dunia pendidikan pelanggannya adalah siswa dan orang tua siswa. Pelanggan tersebut merupakan orang yang berinteraksi dengan sekolah melalui proses belajar mengajar. Dalam organisasi ada dua komponen yang saling berkaitan yaitu pelanggan dan pemasok (Sallis, 1993:31) mengungkapkan bahwa ada dua jenis pelanggan yaitu pelanggan eksternal dan pelanggan internal. Pelanggan eksternal dibedakan lagi menjadi tiga yaitu pelanggan eksternal utama adalah 
pelanggan yang secara langsung menerima layanan, pelanggan eksternal sekunder (seperti orangtua dan kepala daerah), dan pelanggan eksternal tersier adalah pelanggan yang tidak secara langsung berada dalam lingkup pendidikan (perusahaan). Sementara fokus setiap sekolah adalah pada pelanggan eksternal yang berhubungan langsung dengan peserta didik, orangtua dan pemerintah. Kemudian pelanggan internal yang ada dalam sekolah adalah anggota staf yang ada pada sekolah.

Beberapa definisi mengenai kepemimpinan, diantaratanya adalah: (Northouse dan Peter, 2013:5) mendefinisikan kepemimpinan sebagai "Leadership is process hereby an individual influences a group of individuals to achieve a common goal'. Sedangkan kaitannya dengan TQM, definisi yang diberikan oleh Goetsch \& Davis (2000:241) adalah sebagai berikut: "Leadership is the ability to inspire people to make a total, willing, and voluntary commitment to accomplishing or exceeding organizational goals". Dari kedua definisi di atas dapat disimpulkan bahwa kepemimpinan adalah kemampuan seseorang individu untuk mempengaruhi dan mengispirasi sekelompok individu untuk membuat komitmen secara total dan bersedia secara sukarela untuk mencapai atau bahkan melebihi tujuan bersama. Hal ini sesuai dengan hasil penelitian Selesho (2014:322) sebagai berikut "...as majority of the teacher were prepared to work cooperatively with the new leader. They felt that the principal is bringing hope to the school and this renews their commitment and made them want to contribute more to the school." Sallis (1993:169) berpendapat Kepemimpinan adalah unsur penting dalam TQM. Pemimpin harus memiliki visi dan mampu menerjemahkan visi tersebut ke dalam kebijakan yang jelas dan tujuan yang spesifik. Kemudian pendapat lain tentang efektifitas kepemimpinan dikemukakan oleh Gaspersz (2002:199) sebagai berikut: Kepemimpinan yang efektif menurut konsep manajemen kualitas adalah kepemimpinan yang sensitif atau peka terhadap perubahan dan melakukan pekerjaannya secara terfokus. Dari kedua pendapat di atas dapat disimpulkan bahwa pemimpin harus memiliki visi dan mampu menterjemahkannya kedalam kebijakan yang sensitif atau peka terhadap perubahan dan melakukan pekerjaa secara terfokus. Jika digabungkan atara pengertian kepemimpinan dengan kepemimpinan yang berkaitan dengan TQM dapat disimpulkan bahwa seorang pemimpin harus mampu menginspirasi dan mempengaruhi sekelompok individu untuk mencapai visi dan mampu menterjemahkannya kedalam kebijakan yang sensitif atau peka terhadap perubahan dan melakukan pekerjaa secara terfokus dan bekerjasama secara sukarela

Penelitian Sutantri \& Suranto (2013:1) menunjukkan bahwa, dalam implementasi sistem manajemen mutu ISO harus direncanakan kesesuaian sistem terkait dengan standar yang harus dipenuhi, perlunya sosialisasi agar semua elemen sekolah mengetahui komponen dan fungsi ISO 9001:2008 secara terperinci, audit internal dan eksternal perlu dilakukan melalui pengecekan terhadap proses pelayanan yang berjalan, dan fungsi implementasi, dan ISO mendorong penyempurnaan kinerja organisasi sekolah yang berorientasi pada perbaikan manajemen sekolah untuk kepuasan pelanggan. Hasil penelitian menunjukkan bahwa terdapat pengaruh yang positif dan signifikan antara SMM ISO 9001: 2008 terhadap kinerja guru di SMK Negeri 1 Sedayu Bantul.

Permasalahan yang terjadi di lapangan adalah sekolah belum melakukan survei kepuasan pelanggan sehingga belum diketahui sejauhmana kepuasan pelanggan itu diperoleh. Selain itu sekolah belum melaksanakan evaluasi implementasi SMM ISO 9001:2008 sehingga sejauhmana SMM ISO 9001:2008 tersebut dapat dilaksanakan di lapangan. Oleh karena itu perlu dilakukan penelitian untuk mendeteksi hambatan 
yang terjadi serta penyelesaiannya dengan demikian dapat dipergunakan sebagai acuan untuk meningkatkan mutu sekolah.

\section{METODE}

Jenis Penelitian

Jenis penelitian ini adalah penelitian deskriptif dengan desain penelitian campuran (mixed methodology). Mixed method menghasilkan fakta yang lebih komprehensif dalam meneliti masalah penelitian, karena peneliti memiliki kebebasan untuk menggunakan semua alat pengumpul data sesuai dengan jenis data yang dibutuhkan. Sedangkan kuantitatif atau kualitatif hanya terbatas pada jenis alat pengumpul data tertentu saja. Desain campuran antara kuantitatif dan kualitatif ini digunakan untuk mendeskripsikan implementasi SMM ISO 9001:2008. Menurut Abbas \& Charles (2010:vii) mixed method adalah metode yang memadukan pendekatan kuantitatif dan kualitatif dalam hal metodologi (seperti dalam tahap pengumpulan data), dan kajian model campuran memadukan dua pendekatan dalam semua tahapan proses penelitian. Mixed method juga disebut sebagai sebuah metodologi yang memberikan asumsi filosofis dalam menunjukkan arah atau memberi petunjuk cara pengumpulan data dan menganalisis data serta perpaduan pendekatan kuantitatif dan kualitatif melalui beberapa fase proses penelitian.

Waktu dan Tempat Penelitian

Penelitian ini dilaksanakan di SMK Ma'arif 1 Wates, Kulon Progo, Yogyakarta pada bulan Mei 2014 sampai dengan bulan Juni 2014.

\section{Subjek Penelitian}

Dengan sasaran penelitian pada implementasi sistem manajemen mutu (SMM) ISO 9001:2008 di sekolah tersebut, maka subyek penelitian dapat ditentukan seperti pada tabel berikut:
Tabel 1. Subyek dan Sampel

\begin{tabular}{|c|c|c|}
\hline Subyek & Jumlah & Sampel \\
\hline Kepala Sekolah & 1 & 1 \\
\hline Kepala & 5 & 5 \\
\hline Sekolah & & \\
\hline Ketua unit kerja & 4 & 4 \\
\hline QMR & 1 & 1 \\
\hline Guru & 92 & 75 \\
\hline Peserta didik & 426 & 19 \\
\hline Orang tua atau wali & 426 & $\begin{array}{r}5 \\
195\end{array}$ \\
\hline Total & 955 & 476 \\
\hline
\end{tabular}

Prosedur

Prosedur pengumpulan data yang digunakan dalam penelitian ini, peneliti menggunakan beberapa metode/teknik pengumpulan data yaitu analisis dokumen, angket (kuesioner) dan wawancara. Peneliti menggunakan angket (kuesioner) untuk mengumpulkan data primer, sedangkan analisis dokumen dilakukan untuk mengumpulkan data pendukung dan wawancara digunakan untuk melakukan triangulasi data.

Data, Intrumen, dan Teknik Pengumpulan Data

Instrumen yang digunakan adalah angket, pedoman analisis dokumen dan pedoman wawancara. Instrumen penelitian yang berupa angket dikatakan baik apabila valid dan reliable. Pada penelitian ini validitas internal/rasional yang digunakan adalah construct validity (validitas konstrak). Instrumen disusun berdasarkan teori yang relevan kemudian dikonsultasikan dengan para ahli (expert judgment). Kemudian melakukan uji coba instrumen untuk mendapatkan validitas eksternal atau empiris. Sebagai langkah berikutnya, butir-butir angket yang valid diuji reliabilitasnya. Suatu instrumen dikatakan mempunyai tingkat kepercayaan yang tinggi jika instrumen tersebut dapat memberikan hasil yang tetap. Instrumen dinyatakan reliable jika $\mathrm{r}_{11} \geq 0,70$. Hal ini sesuai dengan pendapat Fraenkel \& Wallen (2007:161) yang menyatakan bahwa "For research purposes, a useful rule of thumb is that 
reliability should be at least .70 and preferably higher".

Table 2. Hasil Uji Reliabilitas Angket

\begin{tabular}{cccc}
\hline $\begin{array}{c}\text { Respon } \\
\text { den Uji } \\
\text { Coba }\end{array}$ & $\begin{array}{c}\text { Variabel/ } \\
\text { Aspek } \\
\text { yang } \\
\text { Diukur }\end{array}$ & $\begin{array}{c}\text { Koefisien } \\
\text { Reliabili } \\
\text { tas }\end{array}$ & $\begin{array}{c}\text { Reliabel } \\
\text { / Tidak } \\
\text { Reliabel }\end{array}$ \\
\hline Siswa & $\begin{array}{l}\text { Fokus } \\
\text { Pada } \\
\text { Pelanggan }\end{array}$ & 0,824 & Reliabel \\
& $\begin{array}{l}\text { Kepemimp } \\
\text { inan }\end{array}$ & 0,815 & Reliabel \\
& $\begin{array}{l}\text { Partisipasi } \\
\text { Karyawan }\end{array}$ & 0,964 & Reliabel \\
\hline Orang & $\begin{array}{l}\text { Partisipasi } \\
\text { tua } \\
\text { siswa }\end{array}$ & 0,959 & Reliabel \\
\hline
\end{tabular}

Teknik Analisis Data

Data yang telah terkumpul yang berupa angket, analisis dokumen, dan wawancara tidak akan bermakna tanpa dianalisis yaitu diolah dan diinterpretasikan. Dalam penelitian ini analisis datanya menggunakan statistik deskriptif. Menurut (Sugiyono, 2013:199) statistik deskriptif adalah statistik yang digunakan untuk menganalisis data dengan cara mendeskripsikan atau menggambarkan data yang telah terkumpul sebagaimana adanya tanpa bermaksud membuat kesimpulan yang berlaku untuk umum atau generalisasi.

Langkah-langkah yang dilakukan dalam penelitian ini adalah melakukan proses entri data yang diterima dari responden. Selanjutnya adalah penjumlahan skor yang diperoleh dari hasil observasi, analisis dokumen, penjumlahan skor jawaban angket tiap responden, perhitungan modus, median, mean, perhitungan desil, persentil, perhitungan penyebaran data melalui perhitungan rata-rata, dan standar deviasi menggunakan program statistika SPSS 17.

Mendeskripsikan data dilakukan agar data yang telah diorganisir menjadi bermakna. Bentuk deskripsi tersebut dapat berupa naratif, grafik atau dalam bentuk tabel. Dalam menentukan hambatan yang terjadi dalam implementasi SMM ISO
9001:2008 adalah berdasarkan perolehan nilai ditambahkan dengan data hasil wawancara sehingga data yang diperoleh menjadi lebih lengkap. Kemudian hambatan yang ditemukan dicari penyelesaiannya berdasarkan klausul yang ada pada SMM ISO 9001:2008 dan ditambahkan dengan hasil wawancara sebagai langkah konkrit dalam penyelesaiannya. Tahap terakhir adalah membuat kesimpulan dari data yang telah dideskripsikan. Tahap menganalisis dan menginterpretasikan data merupakan tahap yang paling penting karena hal ini untuk memberikan makna dari data yang telah dikumpulkan. Hasil analisis dan interpretasi data merupakan jawaban dari rumusan masalah yang telah ditentukan sebelumnya.

\section{HASIL DAN PEMBAHASAN}

Hasil Penelitian

Dari hasil penelitian diperoleh gambaran untuk masing-masing variabel diperoleh hasil seperti pada tabel 3 berikut sebagai berikut:

Tabel 3. Hasil Capaian Masing-masing Variabel

\begin{tabular}{clr}
\hline No & \multicolumn{1}{c}{ Variabel } & $\begin{array}{c}\text { Hasil } \\
\text { Capaian }\end{array}$ \\
\hline 1 & Fokus pada pelanggan & $83,95 \%$ \\
2 & Kepemimpinan & $65,53 \%$ \\
3 & Partisipasi karyawan & $76,67 \%$ \\
4 & Pendekatan proses & $72,00 \%$ \\
5 & Pendekatan sistem & $75,00 \%$ \\
6 & Perbaikan berkelanjutan & $75,13 \%$ \\
7 & Pendekatan faktual & $64,00 \%$ \\
8 & Hubungan pemasok & $74,64 \%$ \\
\hline Rata-rata Capaian & $73,37 \%$ \\
\hline
\end{tabular}

Variabel fokus pada pelanggan memperoleh nilai sebesar 83,95\%. diperoleh dari rata rata nilai instrumen pengamatan dokumen mutu guru, angket untuk QMR, kepala sekolah, WKS, siswa dan KUK. Perolehan masing masing responden dapat dilihat pada tabel berikut ini. 
Tabel 4. Hasil Fokus Pada Pelanggan

\begin{tabular}{clr}
\hline No & \multicolumn{1}{c}{ Responden } & \multicolumn{1}{c}{$\begin{array}{c}\text { Variabel Fokus } \\
\text { Pelanggan }\end{array}$} \\
\hline 1 & Dokumen Mutu Guru & $94,60 \%$ \\
2 & Angket QMR & $80,00 \%$ \\
3 & Angket Kepala Sekolah & $80,00 \%$ \\
& Angket WKS dan & $74,18 \%$ \\
4 & KUK & $76,38 \%$ \\
5 & Angket Siswa & $83,95 \%$ \\
\hline Hasil capaian
\end{tabular}

Perolehan nilai terbesar berada pada instrumen pengamatan dokumen mutu guru hal ini disebabkan dokumen mutu guru yang diamati adalah dokumen mutu guru pada semester gasal tahun 2013/2014 sehingga memungkinkan guru telah melengkapi dokumen sebelumnya. Kemudian dari data hasil wawancara dengan QMR diperoleh informasi bahwa kepuasan pelanggan merupakan tujuan akhir dari implementasi SMM ISO 9001:2008. Sekolah telah melakukan survey kepuasan pelanggan namun sekolah belum melakukan analisis hasil survey tersebut hal ini disebabkan kurangnya sumber daya manusia yang menangani survey tersebut. Sehingga tingkat kepuasan pelanggan belum bisa diketahui.

Variabel kepemimpinan diperoleh dari angket untuk QMR, angket untuk WKS dan KUK, dan angket untuk siswa tercantum pada tabel 5 berikut.

Tabel 5. Hasil Perhitungan Kepemimpinan

\begin{tabular}{llr}
\hline No & Responden & $\begin{array}{c}\text { Variabel } \\
\text { Kepemimpinan }\end{array}$ \\
\hline 1 & Angket QMR & $60,00 \%$ \\
3 & Angket WKS dan & $68,60 \%$ \\
& KUK & \\
5 & Angket Siswa & $70,36 \%$ \\
\hline \multicolumn{2}{l}{ Hasil capaian } & $65,53 \%$ \\
\hline
\end{tabular}

Komitmen kepala sekolah dalam penyusunan sistem manajemen mutu perlu ditingkatkan lagi. Rerata tingkat implementasi prinsip manajemen kepemimpinan adalah 66\%. Kemudian hasil wawancara yang dilakukan dengan QMR diperoleh informasi bahwa kepala sekolah telah berkomitmen dalam implementasi SMM ISO 9001:2008. Hal ini dibuktikan dengan telah terlaksananya penerapan SMM ISO di sekolah ini. Namun masih ada kendala yang dihadapi dalam penerapan SMM ISO 9001:2008 yaitu kesibukan kepala sekolah. Kemudian upaya dalam penyelesaian kendala yang dihadapi tersebut kepala sekolah dibantu oleh wakil kepala sekolah dalam penyelesaian tugasnya yang berhubungan dengan implementasi SMM ISO 9001:2008.

Variabel dukungan (participation) karyawan berdasarkan data yang diperoleh dari hasil angket untuk QMR, angket kepala sekolah, angket untuk WKS dan KUK, angket untuk orang tua / wali siswa dan angket untuk siswa tercantum pada tabel 6 berikut.

Tabel 6. Hasil Perhitungan Dukungan (Participation) Karyawan.

\begin{tabular}{llr}
\hline No & Responden & $\begin{array}{c}\text { Variabel } \\
\text { Partisipasi } \\
\text { Karyawan }\end{array}$ \\
\hline 1 & Angket QMR & $75,56 \%$ \\
2 & Angket Kepala & $77,78 \%$ \\
& Sekolah & \\
3 & Angket WKS dan & $75,83 \%$ \\
& KUK & \\
4 & Angket Wali Siswa & $68,51 \%$ \\
5 & Angket Siswa & $69,74 \%$ \\
\hline Hasil capaian & $76,67 \%$ \\
\hline
\end{tabular}

Variabel pendekatan proses, pendekatan sistem terhadap manajemen, pendekatan faktual dalam pengambilan keputusan, dan hubungan pemasok yang saling menguntungkan diperoleh dari angket QMR ditampilkan pada tabel 7 berikut ini:

Tabel 7. Hasil Angket untuk QMR.

\begin{tabular}{llr}
\hline No & Variabel & \multicolumn{1}{c}{ Hasil Capaian } \\
\hline 1 & Pendekatan proses & $72 \%$ \\
2 & Pendekatan sistem & $75 \%$ \\
3 & Pendekatan faktual & $64 \%$ \\
\hline 4 & Hubungan pemasok & $74,64 \%$ \\
\hline
\end{tabular}

Variabel perbaikan berkelanjutanan diperoleh dari instrumen angket dari QMR, kepala sekolah, wakil kepala sekolah dan ketua unit kerja 
Tabel 8. Hasil Angket Variabel Perbaikan Berkelanjutan

\begin{tabular}{lll}
\hline No & Responden & $\begin{array}{c}\text { Variabel } \\
\text { Perbaikan } \\
\text { Berkelanjutan }\end{array}$ \\
\hline 1 & Angket QMR & $81,74 \%$ \\
2 & Angket Kepala & $73,04 \%$ \\
& Sekolah & \\
3 & Angket WKS dan & $70,61 \%$ \\
& KUK & \\
\hline Hasil capaian & $75,13 \%$ \\
\hline
\end{tabular}

Dari data di atas dapat digambarkan secara grafik sebagai berikut:

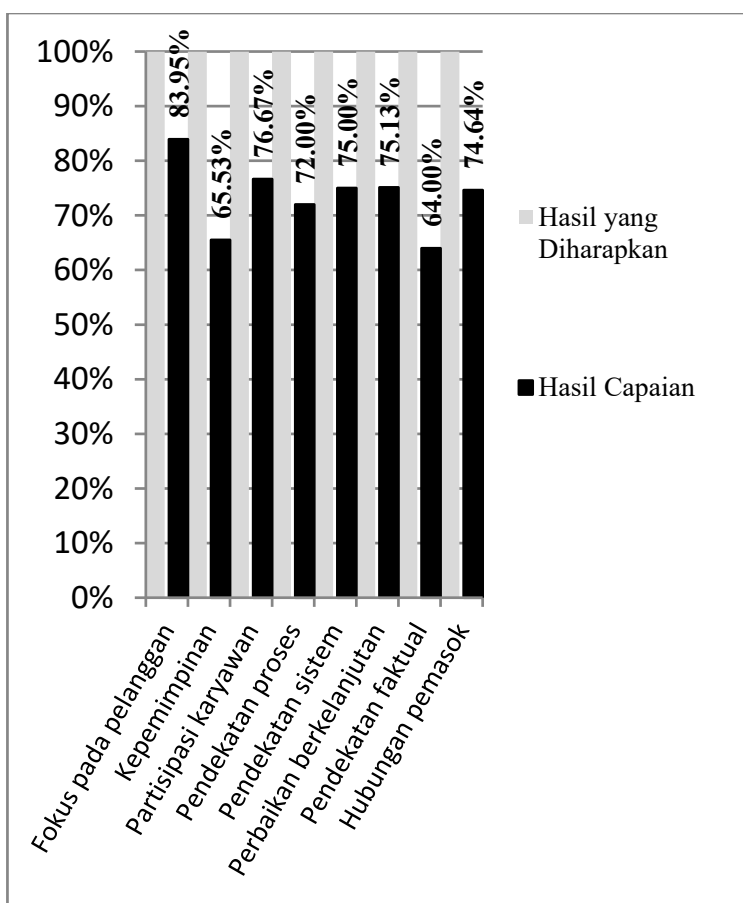

Gambar 1. Hasil Capaian dari Delapan Prinsip Manajemen SMM ISO 9001:2008 di SMK Ma'arif 1 Wates

Pada gambar tersebut tampak bahwa prinsip manajemen yang berfokus pada pelanggan paling kecil tingkat kesenjangannya. Kemudian disusul secara berurutan oleh prinsip manajemen partisipasi karyawan, perbaikan berkesinambungan, pendekatan sistem, hubungan pemasok, pendekatan proses, kepemimpinan, pendekatan faktual keputusan. Rata-rata dari data 8 prinsip manajemen pada SMM ISO 9001:2008 di SMK Ma'arif 1 Wates adaah sebesar 73,35\%. Dengan demikian hambatan dalam implementasi prinsip-prinsip manajemen yang ada pada SMM ISO 9001:2008 di SMK Ma'arif 1 Wates adalah pendekatan faktual dalam pengambilan keputusan dengan tingkat implementasi sebesar 64\%. Kemudian penyelesaian hambatan yang telah teridentifikasi di atas adalah pada prinsip manajemen pada pendekatan faktual dalam pengambilan keputusan dapat diselesaikan dengan melakukan penetapan data yang sesuai untuk sistem manajemen mutu, penghimpunan data yang sesuai untuk sistem manajemen mutu, penghimpunan data yang efektif pada sistem manajemen mutu, analisis data sesuai dengan sistem manajemen mutu, dan analisis data keefektifan sistem manajemen mutu.

Hasil wawancara yang dilakukan dengan QMR diperoleh informasi bahwa kepala sekolah memiliki komitmen yang kuat dalam implementasi SMM ISO 9001:2008. Hal ini dibuktikan dengan telah terlaksananya penerapan SMM ISO di sekolah ini. Kendala yang dihadapi dalam penerapan SMM ISO 9001:2008 pada kepemimpinan ini adalah kesibukan kepala sekolah. Kemudian upaya dalam penyelesaian kendala yang dihadapi tersebut kepala sekolah dibantu oleh wakil kepala sekolah dalam penyelesaian tugasnya yang berhubungan dengan implementasi SMM ISO 9001:2008. Untuk meningkatkan kepuasan pelanggan sekolah memberikan pelajaran tambahan bagi siswa.

\section{Pembahasan}

Dari hasil penelitian di atas kemudian dilakukan pembahasan. Variabel fokus pada pelanggan diukur dengan instrument utama berupa angket untuk siswa. Gambaran yang diperoleh dari hasil perhitungan angket siswa dan hasil pengamatan dokumen mutu guru berbeda jauh. Hal ini disebabkan dokumen mutu guru yang diamati adalah dokumen mutu guru pada semester gasal tahun 2013/2014 sehingga memungkinkan guru telah melengkapi dokumen sebelumnya. Pada bagian selanjutnya tampak bahwa 
implementasi prinsip manajemen fokus pada pelanggan di SMK Ma'arif 1 Wates pada siswa, wakil kepala sekolah, QMR dan Kepala Sekolah memperoleh hasil yang hampir sama.

Hasil wawancara dengan QMR diperoleh informasi bahwa kepuasan pelanggan merupakan tujuan akhir dari implementasi SMM ISO 9001:2008. Sekolah telah melakukan survey kepuasan pelanggan. Kendala yang dihadapi adalah dari hasil survey yang dilakukan belum sampai tahap analisis sehingga tingkat kepuasan pelanggan belum dapat diketahui. Pelaksanaan survei kepuasan pelanggan ini dilakukan ketika orang tua siswa datang kesekolah dalam penerimaan rapot maupun rapat rapat yang dihadiri oleh orang tua siswa.

Variabel kepemimpinan diukur dengan instrument utama berupa angket untuk wakil kepala sekolah dan ketua unit kerja. Gambaran yang diperoleh dari hasil perhitungan angket siswa, angket untuk QMR, angket untuk wakil kepala sekolah dan ketua unit kerja memperoleh perbedaan hasil yang cukup kecil sehingga dapat dikatakan bahwa hasil perhitungan berdasarkan angket untuk QMR, angket untuk siswa mendukung hasil perhitungan tingkat implementasi SMM ISO 9001:2008 berdasarkan angket untuk wakil kepala sekolah dan ketua unit kerja.

Hasil wawancara yang dilakukan dengan QMR diperoleh informasi bahwa kepala sekolah memiliki komitmen yang kuat dalam implementasi SMM ISO 9001:2008. Hal ini dibuktikan dengan telah terlaksananya penerapan SMM ISO di sekolah ini. Kendala yang dihadapi dalam penerapan SMM ISO 9001:2008 pada kepemimpinan ini adalah kesibukan kepala sekolah. Kemudian upaya dalam penyelesaian kendala yang dihadapi tersebut kepala sekolah dibantu oleh wakil kepala sekolah dalam penyelesaian tugasnya yang berhubungan dengan implementasi SMM ISO 9001:2008.

Variabel Partisipasi karyawan diukur dengan instrument utama berupa angket untuk siswa. Gambaran yang diperoleh dari hasil perhitungan angket siswa, angket untuk QMR, angket untuk wakil kepala sekolah, ketua unit kerja dan angket untuk kepala sekolah memperoleh perbedaan hasil yang cukup kecil sehingga dapat dikatakan bahwa hasil perhitungan berdasarkan angket untuk QMR, angket untuk wakil kepala sekolah, ketua unit kerja dan angket kepala sekolah mendukung hasil perhitungan tingkat implementasi SMM ISO 9001:2008 pada angket untuk siswa.

Hasil analisis data berdasarkan angket untuk QMR SMK Ma'arif 1 Wates terlihat bahwa tingkat implementasi SMM ISO 9001:2008 pada variabel pendekatan proses adalah sebesar $72 \%$. Hal ini berarti tingkat implementasi SMM ISO 9001:2008 sebesar 72\%.

Hasil analisis data berdasarkan angket untuk QMR SMK Ma'arif 1 Wates terlihat bahwa tingkat implementasi SMM ISO 9001:2008 pada variabel pendekatan sistem terhadap manajemen adalah sebesar $75 \%$. Hal ini berarti tingkat implementasi SMM ISO 9001:2008 pada prinsip manajemen pendekatan sistem terhadap manajemen sebesar $75 \%$.

$$
\text { Variabel }
$$

perbaikan berkesinambungan diukur dengan instrumen utama berupa angket untuk QMR. Gambaran yang diperoleh dari hasil perhitungan angket untuk QMR, angket kepala sekolah, angket untuk wakil kepala sekolah dan ketua unit kerja, memperoleh perbedaan hasil sehingga dapat dikatakan bahwa hasil perhitungan berdasarkan angket untuk QMR lebih besar dibandingkan dengan yang lainnya hal ini disebabkan QMR lebih mengetahui perbaikan- perbaikan yang ada pada SMM ISO 9001:2008. Dalam melaksanakan perbaikan berkesinambungan ini perlu melaksanakan awarnes SMM ISO bagi tenaga pendidik untuk lebih diefektifkan lagi

Variabel Pendekatan Faktual dalam Pengambilan Keputusan diukur dengan instrument yang berupa angket untuk $Q M R$ SMK Ma'arif 1 Wates terlihat 
bahwa tingkat implementasi SMM ISO 9001:2008 pada variabel pendekatan faktual dalam pengambilan keputusan adalah sebesar $64 \%$. Hal ini berarti tingkat implementasi SMM ISO 9001:2008 pada prinsip manajemen pendekatan faktual dalam pengambilan keputusan sebesar 64\%.

Variabel hubungan pemasok yang saling menguntungkan diukur dengan instrument utama yang berupa angket untuk wakil kepala sekolah dan ketua unit kerja SMK Ma'arif 1 Wates terlihat bahwa tingkat implementasi SMM ISO 9001:2008 pada variabel hubungan pemasok yang saling menguntungkan memiliki perbedaan sangat kecil. Hal ini dapat dikatakan bahwa hasil perhitungan berdasarkan angket untuk QMR mendukung hasil perhitungan tingkat implementasi SMM ISO 9001:2008 pada angket untuk wakil kepala sekolah dan ketua unit kerja. Yaitu pengendalian pemasok terhadap produk yang dibeli perlu ditingkatkan lagi.

Hambatan yang terjadi dalam pelaksanaan prinsip-prinsip manajemen yang ada pada SMM ISO 9001:2008 di SMK Ma'arif 1 Wates dapat diketahui dengan melihat perolehan nilai dari terkecil dari hasil yang diperoleh dari analisa data. Hambatan yang teridentifikasi adalah pada aspek pendekatan faktual dalam pengambilan keputusan.

Penyelesaian hambatan yang terjadi dalam pelaksanaan prinsip-prinsip manajemen yang ada pada SMM ISO 9001:2008 di SMK Ma'arif 1 Wates diperoleh dari klausul yang ada pada SMM ISO 9001:2008. Penyelesaian yang dapat dilakukan adalah dengan melakukan penetapan data, penghimpunan data yang efektif, dan analisis data keefektifan sistem manajemen mutu.

\section{PENUTUP}

Berdasarkan permasalahan, tujuan penelitian, hasil analisis, dan pembahasan yang dipaparkan pada bab-bab sebelumnya, dapat disimpulkan sebagai berikut:

Implementasi prinsip-prinsip manajemen SMM ISO 9001:2008 masingmasing memperoleh nilai sebagai berikut: fokus pada pelanggan sebesar 83,95\%, kepemimpinan sebesar $65,53 \%$, partisipasi karyawan sebesar $76,67 \%$, pendekatan proses sebesar $72 \%$, pendekatan sistem terhadap manajemen sebesar $75 \%$, perbaikan berkelanjutan sebesar $75,13 \%$, pendekatan faktual dalam pengambilan keputusan sebesar 64\%, hubungan pemasok yang saling menguntungkan sebesar $74,64 \%$.

Hambatan yang terjadi dalam pelaksanaan prinsip-prinsip manajemen yang ada pada SMM ISO 9001:2008 di SMK Ma'arif 1 Wates adalah kurang efektifnya dalam melakukan pendekatan faktual dalam pengambilan keputusan. Penyelesaian hambatan yang terjadi dalam pelaksanaan prinsip-prinsip manajemen yang ada pada SMM ISO 9001:2008 di SMK Ma'arif 1 Wates adalah dengan penetapan data, melakukan penghimpunan data yang sesuai dan efektif, dan analisis data kefektifan sistem manajemen mutu. Untuk meningkatkan kepuasan pelanggan SMK Ma'arif 1 Wates memberikan tambahan pelajaran meskipun baru 3 (tiga) mata pelajaran yang di ujikan secara nasional yaitu matematika, bahasa indonesia dan bahasa inggris.

\section{Saran}

Berdasarkan hasil analisis data, pembahasan, dan simpulan penelitian ini, saran yang dapat disampaikan oleh peneliti adalah sebagai berikut:

SMK yang mengimplementasikan SMM ISO 9001:2008 khususnya SMK Ma'arif 1 Wates perlu meningkatkan prinsip-prinsip manajemen khususnya pendekatan faktual dalam pengambilan keputusan. Dalam meningkatkan prinsip manajemen ini yang perlu dilakukan adalah penghimpunan data yang sesuai dan efektif, dan melakukan analisis data kefektifan sistem manajemen mutu sebelum membuat keputusan. Kepuasan 
pelanggan khususnya kepuasan peserta didik dan orang tua, perlu diupayakan peningkatannya dengan melatih tenaga pendidik dan tenaga kependidikan agar dapat memberikan pelayanan yang terbaik. Sekolah hendaknya berkomitmen untuk menciptakan dan membangun budaya mutu secara terus menerus dan berkesinambungan. Sekolah harus selalu memberikan sosialisasi kepada seluruh warga sekolah agar melaksanakan SMM ISO 9001:2008 secara totalitas.

\section{DAFTAR PUSTAKA}

Abbas, T. \& Charles, T. (2010). Mixed Methodology: Combining Qualitative and Quantitative Approaches. California: Sage Publications.

Arikunto, S. (2010). Prosedur Penelitian: Suatu Pendekatan Praktik. Jakarta: Rineka Cipta

Direktorat Pembinaan SMK. (2012). Garis-garis Besar Program Pembinaan SMK 2012 tentang Panduan Pelaksanaan (Panlak) Program Pembinaan SMK Tahun 2012. Jakarta: Direktorat Pembinaan SMK.

(2013). Garis-garis Besar Program Pembinaan SMK 2013 tentang Petunjuk Teknis (Juknis) Program Pembinaan SMK Tahun 2013. Jakarta: Direktorat Pembinaan SMK.

Feigenbaum, A.V. (1992). Kendali Mutu Terpadu. Jakarta: Erlangga.

Fraenkel, J.R. \& Wallen, N.E. (2007). How Design and Evaluate Research in Education. ( $\sigma^{\text {rd }}$ ed.). New York: McGraw-Hill Companies, Inc.

Gaspersz, V. (2002). Total Quality Management. Jakarta: PT Gramedia Pustaka Utama.

Goetsch, D.L. \& Davis, S.B. (2000). Quality Management ( $3^{\text {rd }}$ ed.). New Jersey: Prentice-Hall.Inc

Hoy, C., et al. (2008). Improving Quality in Education. London: Fatmer Press.

Hoque, K.E., et al. (2011). Site-base management: impact of leader's roles on institutional improvement. African Journal of Business Management. Vol 5:p3623-3629.

International Organization for Standardization. (2005). ISO 9000. Quality Management SystemsFundamentals and Vocabulary $\left(3^{\text {rd }}\right.$ ed). Geneva: ISO.

. (2008). ISO 9001:2008. Quality Management System-requirement (4rd ed.). Geneva: ISO.

Northouse \& Peter, G. (2013). Leadership: Theory and Practice ( $\left.6^{\text {th }} e d.\right)$. Thousand Oaks: Sage Publications Asia-Pacific Pte. Ltd.

Sallis, E. (1993). Total Quality Management in Education. London: Kogan Page Limited.

Selesho, J.M (2014). The role of leadership in organisational regeneration: Incident of school improvement. [Versi Elektronik]. Mediterranean Journal of Social Sciences. 5,7.

Stoner, J. A. F., et al. (1995). Management. New Jersey: PrenticeHall.

Sugiyono. (2013). Statistika untuk Penelitian. Bandung: Penerbit Alfabeta.

Sutantri, R. \& Suranto. (2013). Implementasi sistem manajemen mutu iso 9001:2008 di smk negeri 1 godean yogyakarta (versi elektronik). Jurnal Pendidikan Administrasi Perkantoran. 2, 1-8.

Tjiptono, F. \& Diana, A. (2003). Total Quality Management. Yogyakarta: Andi Offset.

Usman, H. (2013). Manajemen: Teori, Praktik dan Riset Pendidikan. Jakarta: Bumi Aksara. 